\title{
Surgical Technique of Supine Percutaneous Nephrolithotomy in Children
}

\section{Técnica quirúrgica de la nefrolitotomía percutánea en supino en niños}

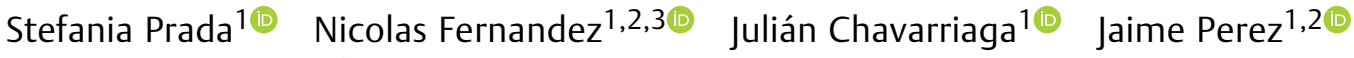 \\ Hugo López-Ramos ${ }^{10}$
}

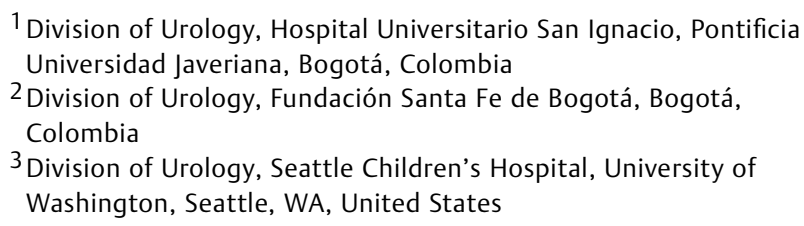

Address for correspondence Stefania Prada Solano, MD, División de Urología, Hospital Universitario San Ignacio, Pontificia Universidad Javeriana, Carrera 7 No. 40-62. Bogotá, Colombia (e-mail: stefania.prada@javeriana.edu.co).

Urol Colomb 2021;30(4):e300-e303.

received

June 29, 2020

accepted

July 2, 2021
Percutaneous nephrolithotomy (PCNL) in children has become more widely used due to its high efficacy and safety and to the development of miniaturized instruments. A supine approach is promising due to advantages such as better ventilation, reproducibility, and ergonomics. The purpose of the present study is to describe our surgical technique with special considerations in the pediatric population. We used an oblique supine position supported by one silicone gel positioning pad under the hip and another under the ipsilateral flank. The anatomical landmarks used to guide the puncture were the $11^{\text {th }}$ and $12^{\text {th }}$ ribs, the posterior axillary line, and the iliac crest. Initially, a ureteral catheter was introduced endoscopically. A retrograde pyelography was performed to guide the puncture, which was performed using a biplanar technique. A hydrophilic guide wire was then advanced through the needle. Dilation was performed with Alken telescopic dilators until $14 \mathrm{Ch}$. Fragmentation was performed either with a $13 \mathrm{Ch}$ semirigid cystoscope or a flexible ureteroscope using a holmium: yttrium aluminum garnet (Ho:Yag) laser. We left a double J catheter. Supine PCNL in the pediatric population has comparable efficacy in terms of stone free rate to that of the prone approach as well as less complications. Certain considerations in children are careful padding and placement of the patient close to the edge of the table. Puncture should be guided by ultrasound to reduce radiation exposure. Miniaturized equipment is not widely available, so adaptation of adult equipment for the pediatric population is sometimes necessary.

stone disease

DOI https://doi.org/

$10.1055 / \mathrm{s}-0041-1733842$. ISSN 0120-789X.

e ISSN 2027-0119. (c) 2021. Sociedad Colombiana de Urología. All rights reserved. This is an open access article published by Thieme under the terms of the Creative Commons Attribution-NonDerivative-NonCommercial-License, permitting copying and reproduction so long as the original work is given appropriate credit. Contents may not be used for commercial purposes, or adapted, remixed, transformed or built upon. (https://creativecommons.org/ licenses/by-nc-nd/4.0/)

Thieme Revinter Publicações Ltda., Rua do Matoso 170, Rio de Janeiro, RJ, CEP 20270-135, Brazil 


\section{Resumen \\ Palabras Clave \\ - nefrolitotomía percutánea \\ - pediatría \\ - posición supina \\ - urolitíasis \\ - nefrolitíasis \\ - miniaturización}

La nefrolitotomía percutánea en niños se ha vuelto ampliamente utilizada por su alta efectividad, seguridad, y por la miniaturización de los instrumentos endoscópicos. El abordaje en supino es prometedor por sus ventajas, como mejor ventilación, reproducibilidad, y ergonomía. El propósito es describir nuestra técnica quirúrgica con las consideraciones especiales a tener en cuenta en la población pediátrica. Todos nuestros pacientes han sido intervenidos bajo la siguiente técnica quirúrgica: en una posición oblicua en supino, utilizando soportes de silicona ubicados debajo de la cadera y del flanco ipsilateral, se marcan los reparos anatómicos: las costillas once y doce, la línea axilar posterior y la cresta ilíaca. Inicialmente se introduce un cateter ureteral por vía endoscópica, con el cual se realiza una pielografía retrógrada para guiar la punción con una técnica biplanar. Se avanza una guía hidrofílica y, sobre esta, los dilatadores telescopados de Alken hasta un tracto de $14 \mathrm{Ch}$. Se realiza la fragmentación con un cistoscopio semirígido de 13 Ch o con un ureteroscopio flexible utilizando el láser Ho: Yag. Se deja un cateter JJ. La nefrolitotomía percutánea en la población pediátrica es comparable en términos de tasa libre de cálculos al abordaje en prono, con menos complicaciones. Una consideración importante en niños es una adecuada posición, cerca al eje de la mesa. La punción debe ser guiada por ultrasonido para disminuir la exposición a radiación. La disponibilidad de equipos miniaturizados es limitada, por lo cual usualmente es necesario adaptar los equipos de adultos.

\section{Introduction}

Management of urinary stone disease is usually based on extracorporeal shock wave lithotripsy (ESWL) or retrograde intrarenal surgery (RIRS). However, in children, there is an increasing use of percutaneous nephrolithotomy (PCNL), which is indicated in the treatment of kidney stones and proximal ureteral stones greater than $20 \mathrm{~mm} .{ }^{1}$ Evidence of high efficacy without compromising safety as well as miniaturization of nephroscopes and advances in intracorporeal lithotripsy fragmentation have contributed to an increasing number of patients treated with this technique.

Historically, it has been performed in a prone position due to a broad surgical field, easy access through a distended pyelocaliceal system and experience on this technique ${ }^{2}$; however the development of a supine approach in adults has shown to be reproducible, more ergonomic for the surgeon, more physiologic for ventilation during surgery and safer in terms tube displacement or cervical trauma, ${ }^{3}$ which is especially relevant in children. ${ }^{4}$ Supine PCNL was first described by Valdivia et al in 1987. He published a series of 557 cases. $^{3}$ In pediatric population, it was first described by Gamal in 2015. ${ }^{5}$ In terms of stone free rate (SFR), supine PCNL is as effective as the prone approach, with a SFR of 74.1 to $92.5 \%{ }^{5}$ versus 86.2 to $98 \%^{2}$ in the prone approach.

The purpose of this video ( - Video 1 -available on-line) is to describe our surgical technique, emphasizing on the details and adjustments of the original technique in the pediatric population with either standard or mini-PCNL tracts and tubeless technique.

\section{Video 1}

Online content including video sequences viewable at: https:// www.thieme-connect.com/products/ejournals/html/ 10.1055/s-0041-1733842.

\section{Surgical Technique}

An adequate positioning is a key step for a successful procedure. We used an oblique supine position supported by one silicone gel positioning pad under the hip and another under the ipsilateral flank. The patient must be placed close to the edge of the table to allow adequate instrument mobility. Padding of the ipsilateral arm that will be rotated to the contralateral side as well as of the face is critical. Anatomical landmarks are used to guide the puncture. We mark the $11^{\text {th }}$ and $12^{\text {th }}$ ribs, the posterior axillary line, and the iliac crest. Two reference anatomical triangles are the Grynfeltt quadrilateral (limited by the $12^{\text {th }}$ rib and the serratus posterior inferior muscle, the posterior border of the internal oblique muscle and the latissimus dorsi) ${ }^{6}$ and the Petit triangle (limited by the iliac crest, the external oblique, and the latissimus dorsi). ${ }^{7}$ To avoid hypothermia, which is essential in children, we use an Ioban drape, which isolates the surgical field and holds a big plastic bag connected at the bottom to suction to maintain the patient dry. Careful padding and protection of the extremities with laminated cotton is performed. Initially, a ureteral catheter is introduced 
endoscopically with a pediatric cystoscope. A retrograde pyelography is performed to guide the puncture. The site of puncture is marked with a Kelly clamp, and, afterwards, the puncture is performed using a biplanar technique, directing the 18-G Chiba needle parallel to the floor and toward the contralateral shoulder guided by ultrasound to reduce exposition to radiation. A hydrophilic guide wire is then advanced through the needle aiming toward the ureter or otherwise coiling it in the collecting system. We use Alken telescopic dilators sequentially until 14 FR following a mini-PCNL approach. In some cases, the Amplatz sheath is too long for the size of the patient, so we must reduce its length by cutting a part of it. Fragmentation is performed either with a 13-Ch semirigid cystoscope or a flexible ureteroscope, depending on the location of the stone and using a holmium: yttrium aluminum garnet (Ho:YAG) laser. We perform a tubeless technique leaving a double J catheter without a nephrostomy tube.

\section{Discussion}

Stone disease in children is less frequent than in adults and is usually related to metabolic abnormalities, with an increasing incidence due to diet modifications and increasing obesity in children. ${ }^{1}$ Endoscopic and percutaneous surgical management is safe and highly effective in children with a SFR calculated around 85.5 and $89 \%{ }^{8}$ Percutaneous nephrolithotomy is recommended in children with pelvic stones $>20 \mathrm{~mm}$ or lower calyx stones $>10 \mathrm{~mm}$, according to the 2019 EAU guidelines. ${ }^{1}$ It has traditionally been performed in a prone approach. However, the multiple advantages of the supine approach evidenced in adults, such as lower thoracoabdominal restriction, easier monitoring of the endotracheal tube and lower risk of cervical and occular trauma,, 10 without compromising effectiveness in terms of SFR 74.1 to $92.5 \%{ }^{5}$ versus 86.2 to $98 \%,{ }^{2}$ have increased popularity in this technique.

Studies available so far, performed by $\mathrm{Gamal}^{5}$ and Bujons, ${ }^{11}$ have shown that supine PCNL in the pediatric population is reproducible and feasible, with comparable efficacy in terms of SFR to the prone approach. This approach also presents less complications, such as postoperative fever, bowel injuries, sepsis, hypothermia, and fluids overload. $5,11,12$

Certain considerations are especially important when working with children, considering the high risk of hypothermia as well as the limited mobility of instruments due to the limited surgical field. Therefore, careful padding as well as an oblique position close to the edge of the table are key factors for an adequate surgical technique. In the pediatric population, puncture should be guided by ultrasound with the intention to reduce radiation exposure, considering the negative effects of radiation in this age group following the as low as reasonably achievable (ALARA) principle. Miniaturized equipment is not widely available, so adaptation of adult equipment for pediatric population is sometimes necessary such as reducing the length of Amplatz sheaths or using pediatric cystoscopes instead of nephroscopes for navigation.

\section{Conclusion}

Supine PCNL is a feasible approach in the pediatric population. However, certain considerations in this age group must be taken into account due to the higher risk of hypothermia, the worse effects of radiation, and the smaller dimensions of the patients. Miniaturized equipment has to be widely available to avoid having to adapt adult equipment to this population.

\section{Ethical Responsibilities}

The present study complies with the World Medical Association (WMA) Declaration of Helsinki Ethical Principles for Medical Research involving Human Subjects, initially developed in 1964 and amended in October 2013. The authors declare there are no conflicts of interest to disclose in the publication of this study. All confidentiality policies have been applied. The current study represents no risk according to the resolution 8430 of 1993 because it is a study that employs "techniques and methods of retrospective documental investigation and those in which no intervention is performed or intentioned modification of the biologic, physiologic, psychologic, or social variables of the individuals who participate in the study."

Patients' confidentiality was respected at all moments, no data that can identify patients have been used, complying with the law 1581 of 2012 . The ethical principles of autonomy, beneficence, nonmaleficence, and justice have been respected. Due to what was previously exposed, no informed consent was needed.

\section{Financial Aid}

No financial aid by any institution was required

Conflict of Interests

The authors have no conflict of interests to report.

\section{References}

1 Tekgül S, Riedmiller H, Gerharz E, et al. EAU Guidelines on paediatric urology. Eur Soc Paediatr Urol Assoc Urol. 2009:1-72

2 Dogan HS, Kilicarslan H, Kordan Y, Celen S, Oktay B. Percutaneous nephrolithotomy in children: does age matter? World J Urol 2011; 29(06):725-729

3 Valdivia JG, Scarpa RM, Duvdevani M, et al; Croes PCNL Study Group. Supine versus prone position during percutaneous nephrolithotomy: a report from the clinical research office of the endourological society percutaneous nephrolithotomy global study. J Endourol 2011;25(10):1619-1625

4 Ozdemir H, Erbin A, Sahan M, et al. Comparison of supine and prone miniaturized percutaneous nephrolithotomy in the treatment of lower pole, middle pole and renal pelvic stones: A matched pair analysis. Int Braz J Urol 2019;45(05):956-964

5 Gamal W, Moursy E, Hussein M, Mmdouh A, Hammady A, Aldahshoury M. Supine pediatric percutaneous nephrolithotomy (PCNL). J Pediatr Urol 2015;11(02):78.e1-78.e5

6 Loukas M, El-Zammar D, Shoja MM, et al. The clinical anatomy of the triangle of Grynfeltt. Hernia 2008;12(03):227-231

7 Loukas M, Tubbs RS, El-Sedfy A, et al. The clinical anatomy of the triangle of Petit. Hernia 2007;11(05):441-444 
8 Figueroa VH, Torres L, Pérez JF, García CF, Prada S. Experiencia quirúrgica en el manejo de litiasis urinaria en la población pediátrica: estudio multicéntrico Surgical Experience in Management of Urinary Lithiasis in Pediatric Population: Multicentric Study.. Urol Colomb 2018;27(03):277-281

9 Cox RG, Ewen A, Bart BB. The prone position is associated with a decrease in respiratory system compliance in healthy anaesthetized infants. Paediatr Anaesth 2001;11(03):291-296

10 Guven S, Frattini A, Onal B, et al; CROES PCNL Study Group. Percutaneous nephrolithotomy in children in different age groups: data from the Clinical Research Office of the Endouro- logical Society (CROES) Percutaneous Nephrolithotomy Global Study. BJU Int 2013;111(01):148-156

11 Bujons A, Millán F, Centeno C, et al. Mini-percutaneous nephrolithotomy with high-power holmium YAG laser in pediatric patients with staghorn and complex calculi. J Pediatr Urol 2016; 12(04):253.e1-253.e5. Doi: 10.1016/j.jpurol.2016.04.027[Internet] 12 Desoky EAE, ElSayed ER, Eliwa A, et al; Flank-free Modified Supine Percutaneous Nephrolithotomy in Pediatric Age Group. Flank-free Modified Supine Percutaneous Nephrolithotomy in Pediatric Age Group. Urology 2015;85(05): 1162-1165 